\title{
Improvement of the calculation and experimental method of evaluation of carbonization of reinforced concrete structures of sewerage underground systems
}

\author{
Mykhailo Sukach¹, Valeriy Chigarov², Ivan Chebotar ${ }^{3}$ \\ ${ }^{1}$ Kyiv National University of Construction and Architecture \\ Povitroflotskiy Avenue 31, Kyiv, Ukraine, 03037 \\ msukach@ua.fm, orcid.org/0000-0003-0485-4073 \\ 2Pryazovskyi State Technical University \\ University Str. 7, Mariupol, Donetsk region, Ukraine, 87500 \\ orcid.org/ 0000-0002-1480-2261 \\ 3 Ukrainian Academy of Sciences \\ Semashka Str. 13, Kyiv, Ukraine, 03142
}

Received 04.08.2021, accepted after revision 24.09.2021

https://doi.org/10.32347/tit2021.42.0203

\begin{abstract}
Carbonization of concrete leads to a decrease in the alkalinity of concrete, an increase in the number of hydrogen ions in the pores, is one of the main factors that lead to corrosion of reinforcement, the formation of cracks and the subsequent reduction of load-bearing capacity of structures. The study of the depth of carbonization of concrete is to determine the $\mathrm{pH}$ of the pore liquid at different depths. There are devices with automatic maintenance of a given concentration of carbon dioxide, to determine the diffusion permeability of concrete to carbon dioxide, based on data on the rate of neutralization (carbonization) of concrete with carbon dioxide. Basically, this method is intended for use in the development of technology and design of concrete composition, providing long-term maintenance of structures in non-aggressive and aggressive gaseous environments, as chips are not prepared immediately before the test and after reaching the design age are placed in the installation with reagents for 7 days. But to determine the carbonization directly on the construction site or object often use the $\mathrm{pH}$ method, i.e. the indicator method of $\mathrm{pH}$ determination. To assess the concentration of hydrogen ions used acid-base indicators - organic substances - dyes, the color of which depends on the $\mathrm{pH}$ from the obtained results the algorithm of definition of depth of carbonization consists in the following actions. The improved formula of definition of
\end{abstract}

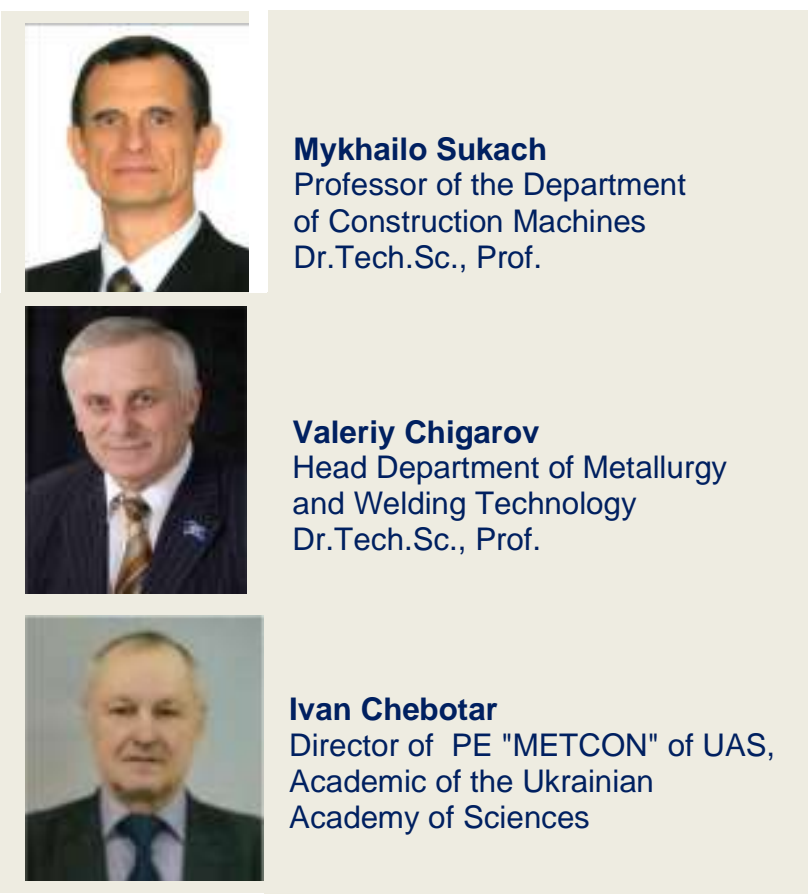

depth of carbonization of concrete taking into account degree of aging and corrosion damages for what in the final formula the corresponding coefficients $\mathrm{k}_{\mathrm{st}}$ and $\mathrm{k}_{\mathrm{kor}}$ are entered: hcarb $=\{(2 \mathrm{D}+\mathrm{C}+\tau) /$ $\left.\left(\mathrm{m}_{\mathrm{o}}+\mathrm{k}_{\mathrm{st}}+\mathrm{k}_{\mathrm{kor}}\right)\right\} 1 / 2$, where the effective diffusion coefficient of $\mathrm{CO}_{2}$ in the concrete of the existing reinforced concrete structure, which is determined by the condition $\mathrm{D}=\left(\mathrm{m}_{\mathrm{o}}+\delta_{2}\right) /(2 \mathrm{C} \cdot \mathrm{t})$. The thickness of the neutralized layer $\delta$ is determined exper- 
imentally on an existing structure using a physicochemical method (phenolphthalein solution or using depth gauges. .Concentration of $\mathrm{CO}_{2}$ in air $\mathrm{C}$ should be determined by chemical analysis of air samples taken directly from the structure or take $\approx$ $0.03 \%$. Re. the ability of concrete mo is determined by the formula $\mathrm{m}_{\mathrm{o}}=0.4(\mathrm{C}+\mathrm{p}+\mathrm{f})$, taking the amount of cement, $\mathrm{kg}$ per $1 \mathrm{~m}^{3}$, respectively, the strength of concrete. neutralization of concrete is equal to $\mathrm{f}=0.5$.

Keywords: carbonization, corrosion, reinforcement, concrete, hydraulic engineering, diffusion.

\section{INTRODUCTION}

Carbonization (neutralization) of concrete is a process of interaction with carbon dioxide $\left(\mathrm{CO}_{2}\right)$ which results in the formation of calcium carbonate with a reduced $\mathrm{pH}$ of the liquid phase of concrete and the loss of passive action on concrete reinforcement (Fig. 1, 2) [1-4].

Moreover, the passive state is a state of the metal in which the speed of the anode process is very limited, ie corrosion is virtually absent.

Influence of chlorides - $65 \%$ carbonization $-5 \ldots 6 \%$ poor quality mortar $-3 \ldots 4 \%$ frost destruction $-5 \%$ fatigue of structures $-5 \%$ construction and installation defects $18 . .20 \%$ This is more clearly illustrated in Fig. $3[3,4]$.

Despite the fact that carbonization occupies only $5 \ldots 6 \%$ of destruction, but its prevalence in recent years in underground sewer- hydraulic reinforced concrete structures has led to the need for urgent study of this important problem for the construction industry $[4,5]$.

According to the analysis of literature sources which are devoted to the problem of carbonization, the main characteristic responsible for the kinetics of carbonization is the diffusion permeability of carbon dioxide $\mathrm{CO}_{2}$ into concrete.

According to Fick's first law, we have

$$
Q=-D+(d c / d \delta),
$$

where $Q$ is the amount of transferred substance that is proportional to the gradient of its concentration $\mathrm{d}_{\mathrm{c}} / \mathrm{d}_{\delta}$; D is the coefficient of proportionality or diffusion coefficient $\mathrm{cm}^{2} / \mathrm{s}$ (it is assumed that the diffusion coefficient does not depend on the gas concentration and time) [7].

The change in concentration with time $\mathrm{dc} / \mathrm{d} \delta$ at point $(\mathrm{x})$ in linear diffusion is determined by Fick's second law

$$
\mathrm{dc} / \mathrm{dt}=\mathrm{D}+(\mathrm{d} 2 \mathrm{c} / \mathrm{d} \delta 2) .
$$

Assuming that the concentration of $\mathrm{CO}_{2}$ in the pores of concrete varies linearly from the value of the concentration in the environment to zero in the zone of chemical interaction, and that the concentration gradient for small time intervals is constant, we can determine the effective diffusion coefficient by the formula

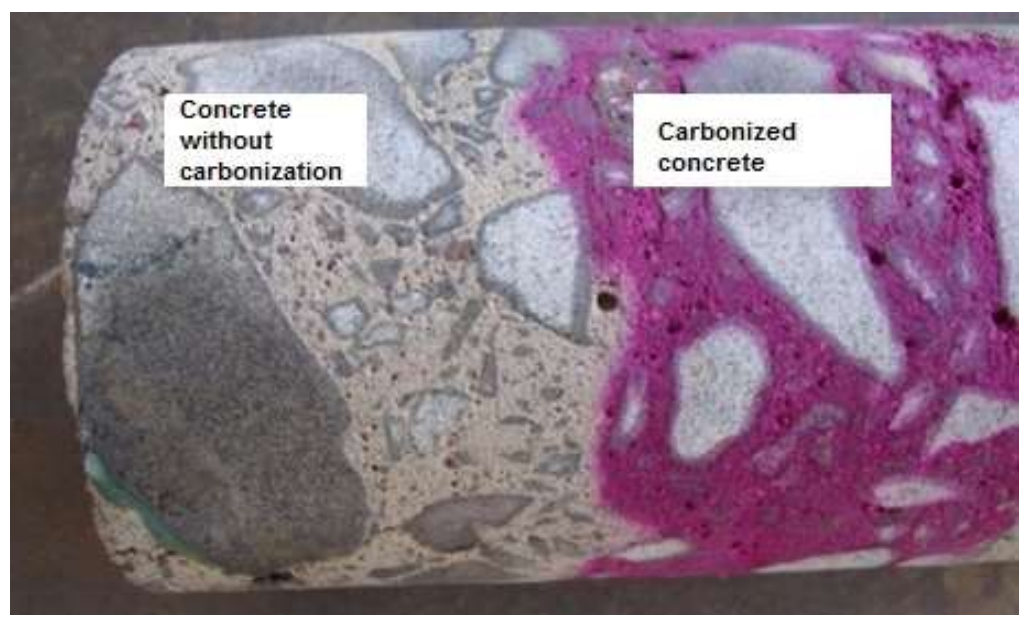

Fig. 1. A concrete sample is taken from the reinforced concrete structure of the underground sewer system 


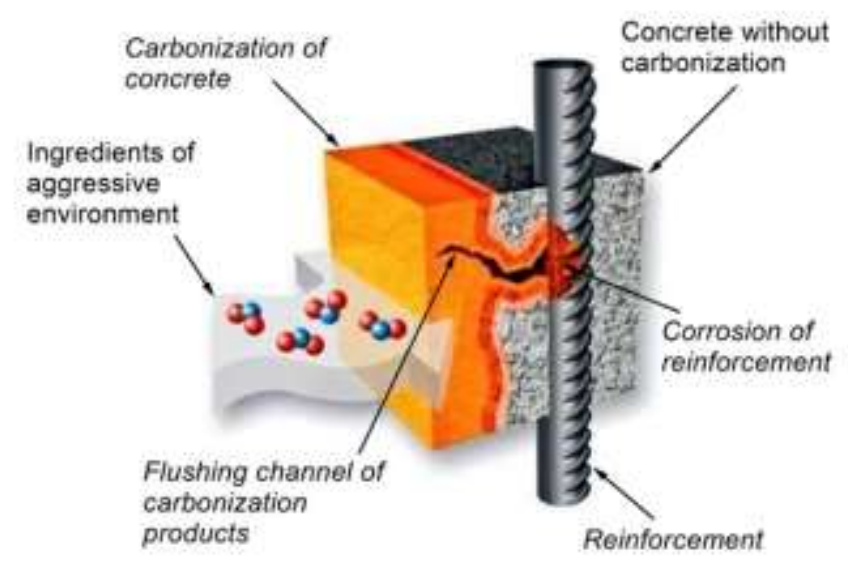

Fig. 2. Schematic representation of the occurrence of corrosion of reinforcing steel

$$
\mathrm{D}=\left(\mathrm{m}_{\mathrm{o}} 2 \delta_{2} / 2 \mathrm{C}+\mathrm{t}\right),
$$

where $\mathrm{D}$ is the effective gas diffusion coefficient in concrete $\mathrm{cm}^{2} / \mathrm{s}$; mo is the reactivity of concrete or the volume of gas absorbed per unit volume of concrete. This value depends on the mineral composition, consumption and degree of hydration of cement and the pore structure of cement stone; $\delta$ is the thickness of the neutralized concrete layer, $\mathrm{mm}$; $\mathrm{t}-$ duration of gas action on concrete, $\mathrm{s}$; $\mathrm{C}$ is the concentration of $\mathrm{CO}_{2}$ in the air in relative terms by volume.

The reactivity of concrete to carbon dioxide can be determined approximately by the formula

$$
\mathrm{m}_{\mathrm{o}}=0.4(\mathrm{C}+\mathrm{p}+\mathrm{f}) \text {, }
$$

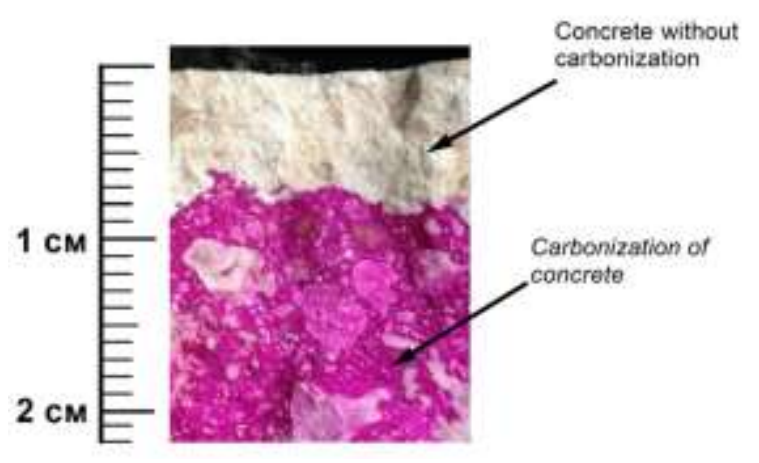

Fig. 3. Scheme of measuring the depth of carbonization

where $\mathrm{C}$ is the amount of cement $\mathrm{kg}$ per $1 \mathrm{~m}^{3}$ of concrete; $p$ is the number of basic oxides in the cement in terms of $\mathrm{CaO}$ in relative terms by weight. Accepted in the calculations according to the chemical analysis of cement; $\mathrm{f}$ is the degree of neutralization of concrete equal to the ratio of the number of basic oxides that reacted with the acid gas to their total amount in the cement.

Since in practice it is often necessary to note the diffusion permeability of existing reinforced concrete structures, for which it is almost impossible to directly determine the parameters $\mathrm{C}$, p, f, they can be determined approximately by the following assumptions. Since the strength of concrete depends on the amount of cement, $\mathrm{kg}$ per $1 \mathrm{~m}^{3}$, you can roughly take $\mathrm{C}$ for concrete:

B25 (M300) - $300 \mathrm{~kg}$; B30 (M400) - 400 $\mathrm{kg}$; B40 (M500) - $500 \mathrm{~kg}$. The concrete strength of the existing reinforced concrete structure can be determined by non-destructive methods.

If it is impossible to perform chemical analysis of cement, the value of $p$ can be taken taking into account the composition of Portland cement $[7,8]$ :

$$
\begin{aligned}
\mathrm{CaO}= & 58-72 \% \mathrm{MgO}=5 \% \mathrm{Na}_{2} \mathrm{O}= \\
& =1-2 \% \mathrm{~K}_{2} \mathrm{O}=1-2 \%,
\end{aligned}
$$

i.e. the value of $\mathrm{p}$ can be taken equal to the average height $\approx 0.7$.

In addition, we can assume that the degree of neutralization of concrete $f$, in which carbonization occurs, based on the conditions of a linear drop in $\mathrm{CO}_{2}$ concentration from the value of the concentration in the environment 
near the concrete surface to zero in the chemical interaction zone is $\mathrm{f}=0.5$.

It should be noted that in many scientific works $[9,10]$ where problems of carbonization of concrete are considered and models of forecasting of its depth of penetration into concrete are offered the main lack, in particular, in such models consequences of aging and corrosion of elements of concrete and reinforcement that obviously overestimates results. theoretical calculations. This shortcoming can be eliminated by entering in the calculation models of the aging coefficients kst and $\mathrm{k}_{\text {kor }}$ corrosion damage [11] k kor.

Table 1 shows the values of the coefficients kst and kkor for reinforced concrete structures of sewer systems depending on the service life (from 0 to 50 years).

Table 1. The value of the coefficients of aging $k_{s t}$ and corrosion $\mathrm{k}_{\mathrm{kor}}$ reinforced concrete structures depending on the service life in underground sewers

\begin{tabular}{|c|c|c|c|c|c|}
\hline \multirow{2}{*}{ Coefficients } & \multicolumn{5}{|c|}{ Service life of structures, years } \\
\cline { 2 - 6 } & 10 & 20 & 30 & 40 & 50 \\
\hline $\mathrm{K}_{\mathrm{st}}$ & 0.7 & 0.6 & 0.55 & 0.5 & 0.45 \\
\hline $\mathrm{K}_{\mathrm{kor}}$ & 0.85 & 0.76 & 0.65 & 0.6 & 0.55 \\
\hline $\mathrm{k}_{\Sigma}$ & 0.595 & 0.456 & 0.38 & 0.3 & 0.25 \\
\hline
\end{tabular}

Note: $\mathrm{k}_{\Sigma}=\mathrm{k}_{\mathrm{st}} \times \mathrm{k}_{\mathrm{kor}}$ is the total degradation coefficient of reinforced concrete structures of sewer systems

Given the above, the formula for determining the depth of carbonization will be as follows:

$$
\mathrm{h}_{\mathrm{karb}}=\left\{(2 \mathrm{D}+\mathrm{C}+\tau) /\left(\mathrm{m}_{\mathrm{O}}+\mathrm{k}_{\mathrm{cT}}+\mathrm{k}_{\mathrm{kor}}\right)\right\} 1 / 2 ;
$$

Then, using the data of Table 1, according to formula (5) we calculate the depth of carbonization of concrete of long service life. The results of the calculation are summarized in Table 2. Attention is drawn to the low error (not more than 5..6\%), which indicates the adequacy of the theoretical calculations of physical and mechanical processes that accompany the carbonization of concrete during the long life of reinforced concrete structures of underground sewerage [12].

Test methods:

- preparation of an alcoholic solution of the indicator $1 \%$ alcoholic solution is used: (1 gram of the drug is dissolved in $80 \mathrm{ml}$ of ethyl alcohol and water is added to a volume of $100 \mathrm{ml}$ ) [11];

- the indicator is applied on a fresh section of concrete made on an experimental structure or on a sample of concrete powder drilled from different depths from several holes. In the $\mathrm{pH}$ range from 8.2 to 10 , the color of the indicator changes from colorless to red-purple. It is believed that when the $\mathrm{pH}$ of the pore fluid in the concrete around the reinforcement decreases to 10 , the concrete loses the ability to reliably protect the reinforcement from corrosion and in the presence of oxygen (oxidized) and moisture (electrolyte) corrosion of the reinforcement can begin. The depth of the carbonization zone from the surface of the structure is measured with a caliper [12].

Thus, it can be emphasized that carbon dioxide $\mathrm{CO}_{2}$, which is in the atmosphere, primarily penetrating into the pores of concrete, tends to neutralize the highly alkaline environment in the presence of moisture, thereby weakening its protective effect against reinforcement. This process is called carbonization concrete - is a complex reaction of conversion of calcium hydroxide into calcium carbonate, which in a simplified form can be written [12]:

$\mathrm{Ca}(\mathrm{OH}) 2+\mathrm{CO}_{2}+\mathrm{H}_{2} \mathrm{O}=\mathrm{CaCO}_{3}+2 \mathrm{H}_{2} \mathrm{O}$.

\section{THE RESULTS OF EXPERIMENTAL AND THEORETICAL RESEARCH AND THEIR DISCUSSION}

Table 1 shows the values of the coefficients of aging and corrosion of structures and Table 2 shows the data for determining the depth of carbonization of concrete depending on the service life of the reinforced concrete structure.

The carbonization process consists of a number of intermediate stages, starting from the surface of the concrete structure from the 
moment of its manufacture and attenuating as carbon dioxide penetrates into the concrete through open pores.

Table 2. Calculated and experimental values of carbonization depth of reinforced concrete structures of underground sewer structures

\begin{tabular}{|c|c|c|c|c|c|}
\hline \multirow{2}{*}{$\begin{array}{c}\text { Depth of } \\
\text { carbonization, } \\
\mathrm{mm}\end{array}$} & \multicolumn{5}{|c|}{ The service life of structures is } \\
\cline { 2 - 6 } & 10 & 20 & 30 & 40 & 50 \\
\hline $\mathrm{h}_{\text {teor }}$ & 7.7 & 20.17 & 36.3 & 61.3 & 91.9 \\
\hline $\mathrm{h}_{\text {exp }}$ & 9.1 & 18.7 & 33.6 & 58.7 & 88.87 \\
\hline
\end{tabular}

Note: The error between theoretical (calculated) and experimental values of the depth of carbonization is not more than $5 . .6 \%$ allowed in engineering calculations

During the reactions, the $\mathrm{pH}$ value of the porous liquid of concrete decreases from the initial values of 12.5 to a level below 9. With limited access of air, iron is not passivated in alkaline solutions having a $\mathrm{pH}$ below $11.3-$ 11.8. Carbonization of concrete is completely completed at $\mathrm{pH}$ values of about 9 . At such $\mathrm{pH}$ values there is a depassation of reinforcing steel (destruction of the protective film), resulting in a risk of corrosion of the reinforcement.

Carbonization of concrete leads to a decrease in the alkalinity of concrete, an increase in the number of hydrogen ions in the pores, is one of the main factors that lead to corrosion of reinforcement, the formation of cracks and subsequent reduction of load-bearing capacity of structures. The study of the depth of carbonization of concrete is to determine the $\mathrm{pH}$ of the pore liquid at different depths. There are devices with automatic maintenance of a given concentration of carbon dioxide, to determine the diffusion permeability of concrete for carbon dioxide, based on data on the rate of neutralization (carbonization) of concrete with carbon dioxide. Basically, this method is in- tended for use in the development of technology and design of concrete composition, providing long-term maintenance of structures in non-aggressive and aggressive gaseous environments, as samples are not prepared immediately before testing and after reaching design age are placed in the installation with reagents for 7 days. However, the $\mathrm{pH}$ method, i.e. the indicator method for determining $\mathrm{pH}$, is often used to determine carbonization directly on a construction site or site. To assess the concentration of hydrogen ions used acid-base indicators - organic substances - dyes, the color of which depends on the $\mathrm{pH}$ of the medium, in this case using phenolphthalein $\mathrm{C}_{20} \mathrm{H}_{14} \mathrm{O}_{4}$.

\section{CONCLUSIONS}

Based on the above, we can conclude the following:

1 The proposed algorithm for determining the depth of carbonization, which consists in the following steps:

Improved formula for determining the depth of carbonization of concrete, taking into account the degree of aging and corrosion damage, for which the final formula introduced the appropriate coefficients $\mathrm{k}_{\mathrm{st}}$ and $\mathrm{k}_{\mathrm{kor}}$ : $\mathrm{h}_{\text {karb }}=\left\{(2 \mathrm{D}+\mathrm{C}+\tau) /\left(\mathrm{m}_{\mathrm{o}}+\mathrm{k}_{\mathrm{st}}+\mathrm{k}_{\text {kor }}\right)\right\} 1 / 2$, where the effective diffusion coefficient of $\mathrm{CO}_{2}$ in the concrete of the existing reinforced concrete structure, which is determined by the condition $\mathrm{D}=\left(\mathrm{m}_{\mathrm{O}+} \delta_{2}\right) /(2 \mathrm{C}+\mathrm{t})$.

2. The thickness of the neutralized layer $\delta$ is determined experimentally on an existing structure using a physicochemical method (phenolphthalein solution or using depth gauges).

3. The concentration of $\mathrm{CO}_{2}$ in the air $\mathrm{C}$ must be determined by chemical analysis of air samples taken directly from the structure or take $\approx 0.03 \%$.

4. The reactivity of concrete mo is determined by the formula $\mathrm{m}_{\mathrm{o}}=0.4(\mathrm{C}+\mathrm{p}+\mathrm{f})$, taking the amount of cement, $\mathrm{kg}$ per $1 \mathrm{~m}^{3}$, according to the strength of concrete. The amount of basic oxides in cement in terms of $\mathrm{CaO}$ to take the average values of $\mathrm{p} \approx 0.7$. Moreover, the degree of neutralization of concrete is taken equal to $f=0.5$. 


\section{REFRENCES}

1. Gaal G.C., 2002. Prediction of deterioration of concrete bridqes in the Notberkands, Barcelona, 526-528 (in Russian).

2. Fediuk R., Yushin A., 2016. Modern technologies of nondestructive testing of construction materials, IOP Conference Series: Materials Science and Engineering 4. Cep. IV International Conference on Modern Technologies for Non-Destructive Testing C. 012001.

3. Fediuk R., 2015. High-strength fibrous concrete of Russian Far East materials, IOP Conference Series: Materials Science and Engineering Cep. International Conference on Advanced Materials and New Technologies in Modern Materials Science, AMNT 2015, C. 012020.

4. Fediuk R., Yushin A., 2015. Composite binders for concrete with reduced permeability In the collection IOP Conference Series Materials Science and Engineering Cep. International Conference on Advanced Materials and New Technologies in Modern Materials Science 2015, AMNT 2015. C. 012021 (Russian)

5. Marinin A.N., Marinin A.N., Garibov R.B., Ovchinnikov I.G., 2008. Resistance of reinforced concrete structures to chloride corrosion and carbonization, Saratov Publishing house, center RATA, 296 (in Russian).

6. Sakharov V.N., Mayorov V.G., 2005. Modern methods of anticorrosive protection of metal structures in hydraulic engineering. Hydraulic engineering, 46-11 (in Russian).

7. Boyko A.V., Makarenko V.D., Maksimov S.Yu., 2021. On some mechanical characteristics of structural steels of cooling systems of long operation. Problems of Strength, No.2, 470 (in Russian).

8. Okada T., Hattori S., 2016. Relationship between salt concentration in water and corrosion fatigue resistance of structural steel containing $0.37 \%$ carbon. Proceedings of the American Society of Mechanical Engineers, Mir Publishing House No.3, 1085, 98-107 (in Russian).

9. Makarenko V.D., Maksimov S.Yu., Vinnikov Yu.L. and others., 2021. Corrosion management of hydraulic engineering equipment, Kiev Vydavnichy Center of NUBIP of Ukraine, 295 (in Ukrainian).

10. Babitsky V.V., 2011. Forecasting the depth of carbonization of concrete of reinforced concrete bridge structuresб Construction Scionce enqineerinq, 2011, 13-16, Belarusian National Technical University (in Russian).

11. Stepanova V.F., 2016. Protection of rein- forcement against corrosion in concrete based on porous aggregates, M OOO Bumazhnik, 192 (Russian).

12. Blikhorsky V.Ya., Struk R.F., 2007. Research of concrete carbonization in reinforced concrete structures, Lviv National University Instutional Repostoriy, 23-27 (in Russian).

13. Olexander Terentyev O., Ievgenii Gorbatyuk Ye, 2020. Data protection by means of firewalls of new generation. Transfer of Innovative Technologies, Vol.3, No.1, 90-92.

14. Pushkarova K., Sukhanevych M., Bondar K., 2015. The principles of composite construction penetrability waterproofing mortars with increased service life. Underwater Technologies, Vol.02, 46-52.

15. Zhuravska N., Malkin E., 2015. Energysaving technologies with the use of water treat the magnetic fields. Underwater Technologies, Vol.02, 79-83.

16. Sukach M.K., 2020. Estimation of the accuracy of engineering calculations of plate springs. Girn., bud., dor. ta meliorat. mashyny, Vyp. 95, 5-13. https://doi.org/10.32347/gbdmm2020. 95.0101 (in Ukrainian).

17. Horbatenko Y., 2020. The production of the splash phenomenon, as a way of dissipating the energy of a gravitational wave. Underwater Technologies, Vol.10, 58-67.

18. Sukach M.K., 2021. The Staple-Shape Plate Springs Engineering Calculation Method. Science and Technique. 20 (3), 268-274. https://doi.org/10.21122/2227-1031-2021-20-3268-274 (in Russian).

19. Maksimov S., Radzievskaya A., Nyrkova L., Osadchuk S., 2021. Corrosion resistance of welded joints made by underwater wet welding. Transfer of Innovative Technologies, Vol.4, No.1, 41-46.

20. Kyryljuk V.S., Levchuk O.I., Gavrylenko O.V., Sukach M.K., 2019. Matematychne modeljuvannja napruzhenogo stanu ortotropnogo p'jezoelektrychnogo materialu zi sferoi'dal'noju porozhnynoju pid vnutrishnim tyskom. Systemni doslidzhennja ta informacijni tehnologii, Vyp.3, 110-117. https://doi.org/10. 20535/SRIT.2308-8893.2019.3.10 (in Ukrainian). 


\section{Улучшение расчетно-экспериментального метода оценки карбонизации железо- бетонных конструкций подземных систем канализации}

\author{
Михаил Сукач, Валерий Чигарев, \\ Иван Чеботар
}

Аннотация. Карбонизация бетона приводит к снижению щелочности бетона, увеличению количества ионов водорода в порах, является одним из основных факторов, приводящих к коррозии арматуры, образованию трещин и последующему снижению несущей способности. вместимость конструкций. Исследование глубины карбонизации бетона заключается в определении $\mathrm{pH}$ поровой жидкости на разной глубине. Существуют устройства с автоматическим поддержанием заданной концентрации углекислого газа, позволяющие определять диффузионную проницаемость бетона для углекислого газа на основе данных о скорости нейтрализации (карбонизации) бетона углекислым газом. В основном этот метод предназначен для использования при разработке технологии и конструкции бетонного состава, обеспечивающего длительное обслуживание конструкций в неагрессивных и агрессивных газовых средах, так как стружка не готовится непосредственно перед испытанием и после достижения проектного возраста помещают в установку с реагентами на 7 суток. Но для определения карбонизации прямо на стройплощадке или объекте часто используют рН-метод, то есть индикаторный метод определения $\mathrm{pH}$. Для оценки концентрации ионов водорода используются кислотно-основные индикаторы - органические вещества - красители, цвет которых зависит от $\mathrm{pH}$. По полученным результатам алгоритм определения глубины карбонизации состоит в следующих действиях. Усовершенствованная формула определения глубины карбонизации бетона с учетом степени старения и коррозионных повреждений, для чего в окончательную формулу вводятся соответствующие коэффициенты $\mathrm{k}_{\mathrm{st}}$ и $\mathrm{k}_{\mathrm{kor}}: \mathrm{h}_{\mathrm{carb}}=\{(2 \mathrm{D}+\mathrm{C}+\tau) /$ $\left.\left(\mathrm{m}_{\mathrm{o}}+\mathrm{k}_{\mathrm{c \tau}}+\mathrm{k}_{\mathrm{kor}}\right)\right\} 1 / 2$, где эффективный коэффициент диффузии $\mathrm{CO}_{2}$ в бетоне существующей железобетонной конструкции, который определяется условием $\mathrm{D}=\left(\mathrm{m}_{\mathrm{o}}+\delta_{2}\right) /(2 \mathrm{C}+\mathrm{t})$. Толщина нейтрализованного слоя $\delta$ определяется экспериментально на существующей конструкции с помощью физико-химического метода (раствор фенолфталеина или с помощью глубиномеров. Концентрация $\mathrm{CO}_{2}$ в воздухе $\mathrm{C}$ должна определяться химическим анализом проб воздуха, взятых непосредственно из конструкции, либо взять $\approx 0,03 \% \operatorname{Re}$. Способность бетона $\mathrm{m}_{\mathrm{o}}$ определяют по формуле $\mathrm{m}_{\mathrm{o}}=0,4(\mathrm{C} \cdot \mathrm{p}+\mathrm{f})$, принимая количество цемента, кг на $1 \mathrm{~m}^{3}$, соответственно прочность бетона. Нейтрализация бетона равна $\mathrm{f}=0,5$.

Ключевые слова: карбонизация, коррозия, армирование, бетон, гидротехника, диффузия. 